\title{
Proceeding
}

\section{Physical and sport education between Italian academic system and European Research Council structure panel}

\author{
TIZIANA D'ISANTO \\ MIUR Campania, Italy
}

\begin{abstract}
Italian academic system is structured on 4 hierarchical levels. The basic level for physical and sports education is composed by 2 academic scientific-disciplines: Methods and Teaching of physical and sports activities to aim to research the theories, techniques and methods for general physical education or addressed to particular groups or age classes and to train and practice for different sports activities, the evaluation of performance and athletic aptitudes. The superior levels are academic recruitment field Didactics, special pedagogy and educational research to aim on Education for physical and sports activities, group of academic discipline field of Pedagogy and, finally, discipline area of historical, philosophical, psychological and pedagogical sciences. While European Research Council consisting of 3 areas: Social Sciences and Humanities, Physical Sciences and Engineering and Life Sciences, 25 panels and 333 subpanels. The aim is to research the scientific identity of physical and sports education in the current framework of rules with the identification and comparison between the systems keywords and subpanel ERC 2018. It was being identified by the 2400 keywords of Italian National University Council: Physical training, learning, human movement and sport education, sport pedagogy, motor development and by the ERC subpanels: Health, Cognitive basis of human development and education, Learning. The comparison between them is complex but configurable and emerges a gap for the two different method settings because of the misalignment between them. The effect is that the Italian system has a dichotomy between research and training with consequences for grant and funding abroad such as the European Research Council. Key words: ERC Areas; ERC Panels; ERC Subpanels; CUN keywords; Academic discipline.
\end{abstract}

\section{Cite this article as:}

D'Isanto, T. (2019). Physical and sport education between Italian academic system and European Research Council structure panel. Journal of Human Sport and Exercise, 14(1proc), S66-S76. doi:https://doi.org/10.14198/jhse.2019.14.Proc1.08

Corresponding author. MIUR Campania, Italy. http://orcid.org/0000-0001-7151-7486

E-mail: tizidisanto@libero.it

Supplementary Issue: Autumn Conferences of Sports Science. Costa Blanca Sports Science Events, 2-3 November 2018. Alicante, Spain.

JOURNAL OF HUMAN SPORT \& EXERCISE ISSN 1988-5202

(c) Faculty of Education. University of Alicante.

doi:10.14198/jhse.2019.14.Proc1.08 


\section{INTRODUCTION}

Italian academic system is structured on 4 hierarchical levels. The basic level for physical and sports education is composed by 2 academic scientific-disciplines: Methods and Teaching of physical and sports activities to aim to research the theories, techniques and methods for general physical education or addressed to particular groups or age classes and to train and practice for different sports activities, the evaluation of performance and athletic aptitudes. The superior levels are academic recruitment field Didactics, special pedagogy and educational research to aim on Education for physical and sports activities, group of academic discipline field of Pedagogy and, finally, discipline area of historical, philosophical, psychological and pedagogical sciences. While European Research Council consisting of 3 areas: Social Sciences and Humanities, Physical Sciences and Engineering and Life Sciences, 25 panels and 333 subpanels.

Currently in Italy, physical and sport education has been placed in two different scientific areas: Social Humanities sciences and Life sciences; the related two academic disciplines are assembled in the Group of academic recruitment field and Academic recruitment field and have differently title respected to the two areas. Methods and teaching of physical and sport activities in SH and Physical training and sport science methodologies in LS. (att. C \& D, DM 355, 2015). The two Academic disciplines are identifiable into Teaching and methods of physical activities and Teaching and methods of sport activities, and take place in scientific area CUN 11 Historical, philosophical, psychological and pedagogical sciences (all. B C D DM 2000).

Physical and sport education is divided into two different scientific areas with different research methods: the pedagogy-didactics and educational framework in an area of human and social sciences, so-called nobibliometric, and the bio-medical one in an area of life sciences, so-called bibliometric.

Non-bibliometric area have book, chapters and articles not indexed in SCOPUS and WOS database as scientific products to evaluate. Bibliometric area have indexed articles in SCOPUS and WOS database, number of citations and $h$-index citations as scientific products and parameter to evaluate. This involves an exceptional scientific ubiquity with difficulties of research assessment, training and, finally, of recruitment or upgrading researcher careers. Regardless of the complexity problem, Movement and sport sciences field needs for stabilizing and simplification in an unique area: Life sciences (bibliometric) or Social sciences and Humanities (not-bibliometric) for an own scientific identity and properly place in academic structure.

European Research Council Executive Agency, ERCEA, has the mission to encourage the highest quality research in Europe through competitive funding and to support investigator-driven frontier research across all field, on the basis of scientific excellence (https://erc.europa.eu/about-erc/mission, 2018). In 2018, European Research Council, ERC updates the Panel Structure and confirms the 3 areas: SH Social Sciences and Humanities - PE Physical Sciences and Engineering - LS Life Sciences and the 25 panels but amount and denomination of the sub panels by increasing them to 333 (https://erc.europa.eu/sites/default/files/document/file/ERC_Panel_structure_2018.pdf, 2018).

Thus, in all of the European Union countries, the academic disciplines in university body have to update to align to the ERC scheme to concerns both the funding of research and the researcher' profiles, including theirs retained rights. In Italian academic body it discusses about the model transformation to respond at the request from the scientific world and so, to align the Italian university model to the ones of European Union. The Italian Government, through the Ministry of University has to rearrange and reorganize the university research model to interact effectively to university body of the other countries. The model has four hierarchical 
levels: the Academic scientific discipline, the Academic recruitment field and Group of academic recruitment field (att. D DM 355, 2015), and they are structured in each of the 14 scientific areas of Italian National University Council (CUN) (law 18, 2006). It does not have the similarity to the European Research Council Panel Structure (ERC Panel Structure, 2018); so there are the difficulties of evaluating Italian research projects and to found grant funding to it. Academic disciplines are structured in an atypical mode that, compared to those of others European countries, needs, in addition, the appropriate equivalences between the academic positions of Italian researchers to those of EU. Which means that the health, sport performance and physical and sport education have been assessing together by the same model without the different among them from the different bibliometric and not-bibliometric point of view. In addition, that is also found in the different translations of the titling of Academic disciplines: when regarding health and education one is: Teaching and methods of physical and sport education in Social sciences and Humanities when regarding sport performance and assessment the title is Physical training and sport science methodologies in Life Sciences. So the opportunity for the rearrangement/reorganization and simplification of the academic structure is also an opportunity to solve the problem just exposed. Nowadays, the problem is to choose in which scientific area, the Physical and sport education, has to be placed or to distribute its specific contents in all sub panels according to ERC scheme. At the end, it treats the Movement and sport science perspective by passing through the Italian University National Council (CUN) keywords (CUN, 2016) of academic disciplines and research domains.

The aim is to research the scientific identity of physical and sports education in the current framework of rules with the identification and comparison between the systems keywords and the ERC subpanels 2018.

\section{BRIEF HISTORY OF ITALIAN PHYSICAL AND SPORT EDUCATION}

Before the first great war there were several aspects that give a meaningful since the kingdom of Italy on physical and sport education. In 1878, Francesco De Sanctis is the promoter of a norm that opens the way to a teaching characterized by highly educational purposes even if the military nature of gymnastics remains; after having redefined the discipline, renaming it "educational gymnastics", which at the end of 1800 became "Physical Education", emanates a law that deals entirely with the subject (Law n. 4442, 1878), which makes teaching of educational gymnastic in schools compulsory and which establishes the compulsoriness the teaching of educational gymnastic even for women in schools of all grades. This law states, however, that the programs are agreed on the basis of a close confrontation between the Minister of Education and the Minister of War, and decrees that the teachers are recruited from the military personnel. In the early years of the 20th century, it was made obligatory, at university students of any faculty who had aspired to a middle school diploma, to attend special master classes in physical education at the respective medical faculties, while the normal gymnastics schools of Rome, Turin and Naples were transformed into institutes of teaching for habilitation at the teaching of physical education. In 1923 there was a structural reform of the Italian school system developed by the neo-idealist philosopher Giovanni Gentile in collaboration with the researcher Giuseppe Lombardo Radice; this law, established by the legislative decrees issued by the government virtue of the delegation conferred by Parliament, redraws the conceptual and operational structure that will characterize the Italian school formally until the beginning of the 20s. Specifically, although physical education occupies an interesting position within the strict pedagogical system of Giuseppe Gentile (Gentile $2004,1993,1990)$, since the education of the body is aimed at forming the moral character and the will of each student and the body is considered in its spiritual essence, it is spin off from secondary school programs, even if it continues to be present in the program for preparatory and elementary schools and magisterial institutes; providing that the pupils of all governmental schools and matched employees from the Ministry of Education will complete their physical education at the designated gymnastic and sportive clubs (Pasqualini, 
2014). During the Fascist period, therefore, the teaching of physical education, characterized by a strong nationalist and paramilitary ideological model (Ponzio, 2008), is assigned to extra-scholastic bodies (Ledeen, 1969), such as the National Body for Physical Education (ENEF), the National Opera Balilla (ONB) and the Italian Youth of the Littorio (GIL). The collapse of the fascist regime (Cassata \& Building, 2011), in 1943, drags all party organizations with it: after twenty years, physical education returns to the Ministry of Education, in terms of discipline; the emancipatory process from the ideological-military models of the previous period is, however, slow and difficulty: the ascending and descending phases that alternate in this process are outlined thanks to an analysis of the meanings attributed to physical education in teaching programs and in disposals that have occurred over time. After the cessation of the Fascism, PE academies for about a decade, no institution took over its functions until the academic year 1952/1953, when the Institute of PE of Rome (ISEF) began to function. The establishment of similar state institutions was also planned. On the basis of this provision, the following ISEFs were set up in Turin (1959), Naples and Bologna (1960), Florence (1963), Milan (1964), Palermo (1965), Perugia and Urbino (1967), of the Lombardia based in Milan and L'Aquila (1968). The regulation of the ISEFs included three-year courses of study divided into distinct male and female sections. At the end of these courses the students received a diploma, an academic qualification required for the teaching of physical and sport education in secondary schools. The second after war was a dark period for physical and sport education because there was an intense and long political reaction, totally replaced with respect to the previous political regime. The physical and moral exaltation of the race, contained in the racial laws of the kingdom of Italy extended to all possible fields including that of PE and sport science, beyond as an instrument of military offense and of social and cultural segregation, was also a significant element which had also permeated layers of the society. The issue of physicality, performance and physical beauty linked to physical exercise had strongly deluded public opinion to such an extent that it did not suggest that this exaltation had contributed to bring in Italy to the brink of social abyss. With the change of regime and the consequent new political class, the concern of a return to the drifts of the past grew due to the fascination that the theme of a strong and vigorous body could still provoke. The new state apparatus, constituted in the new republican form, therefore relegated the physical and sport sciences to limbo waiting for better times with the conviction to remove the past conditioning and at the same time to reduce the understandable reactions to the disaster caused by the previous politics. Thus, began a period of absolute inertia, which lasted 13 years after the second great war, in which it was decided to rebuild the physical and sport education within the education and university without having however in any consideration the contribution that a physical education and culturally renewed sport could and should give. Everything was suspended and only in the elementary schools with the Ermini programs in 1955 there was a little bit presence of the physical activity even if it debased its specific and educational contents. In the other grades of schools $\mathrm{PE}$ was left to a state of total abandonment because it was entrusted to personnel unqualified, coming from other professions, through a direct call recruitment that did not provide any training at all. In 1958, thanks to the political acumen of the then Minister of Education, Aldo Moro, the PE subject was stabilized in secondary school (lower and high school), the organic role of the teachers of Physical Education PE was constituted and, years after the abolition of the Academies of Rome and Orvieto, were instituted the Higher Institutes of Physical Education with the task of training the PE teachers. At the same time on the sporting side, the institutional political apparatus initiated the same action of reaction to the physical and moral exaltation of the race, appointing the liquidator commissioner (Giulio Onesti) of the Italian National Olympic Committee, CONI, (law 426, 1942) a body endowed with legal personality. However, he did not comply with the mandate given to him and made the CONI reborn, depleting it of those principles and mechanisms characterizing the fascist period and consolidating its organizational and managerial aspects. The CONI became, in addition that the confederation of sports federations, also a real body in substitution of the Italian government with tasks of development of sport and financed with the economical governmental resources. Promoted the establishment of new national sports federations, strengthened the existing ones, instituted the sports 
promotion and was hierarchically structured with a self-sufficient regulation that ensured its complete autonomy from politics. It replaced the Italian government in the training of sports technicians, built and ran sports facilities and slowly with a progressive collaboration began to be an indispensable partner for the School. The Youth games, the Student championships and the special projects for physical and sport education in the Elementary/Primary school were carried out. From time CONI projects: Physical literacy and Sport class are the basis of physical and sport education in the Primary school. So, also for extra school activity the physical activity had an absolute stop in order to the past philosophy and social value. As it tells before, the act of birth of Movement and sport science after the Second world war was the law that established the Higher Institutes of Physical Education (ISEF). The law n. 88 of 7 February 1958, in Title III article 22 et seq., instituted the higher institutes of PE of university degree. The institutes (11) were equalized to the only public, the one already existing in Rome, the only one that had specific funding from the government and that also subsequently retained the prerogative of a leading academic venue for Movement and sport science. As a result of the equalization, the ISEF issued three-year academic qualifications with legal value, called a diploma to distinguish them from the degree that at the time generally had a four-year course of study while having the same legal weight. Thus, in 1958, began the restart of physical and sport education but with a different academic level to the others subject in the school and in university system.

\section{BRIEF CONTEMPORARY HISTORY}

After almost 40 years from 1958 the Italian Government and Parliament decided to reform the ISEF in same hierarchical level of the others field of knowledge so it ranked them in university status. The Italian Parliament and Government issued the Legislative Decree 8 May 1998, n. 178 "Transformation of Higher Institutes of Physical Education and Establishment of Faculties and Degree and Diploma Programs in Movement and sport science, in accordance with the article 17, comma 115 of law Bassanini bis the (Law 127, 1997). Thus, the new Academic discipline is established by the academic body and it is called Physical training and methodologies sciences to address also the educational goal. M-EDF/01 - METHODS AND TEACHING OF PHYSICAL ACTIVITY or PHYSICAL TRAINING AND METHODOLOGY SCIENCES. Its declination is following: Movement science: The sector, referable to the one called "sciences of physical activity" established by the legislative decree of May 8th, 1998 n.178, deals with the development and teaching of theories, techniques and methods for general physical and motor education or aimed at particular groups or age classes.

a) Theory and methodology of human movement.

b) Theory, technique and didactic of physical activity for the developmental age.

c) Theory, technique and didactic of physical activities for adulthood and elderly.

d) Theory, technique and didactic of group activities, recreational and free time.

e) Theory, technique and didactic of "adapted" physical and sport activities.

f) Theory, technique and didactic of preventive and compensative physical education.

The law n. 240 of 30 December 2010 defined the Academic recruitment field and Group of academic recruitment field aggregating the academic disciplines, so the Ministerial Decree no. 336 of 29 July (2011), Determination of the Academic recruitment field and Group of academic recruitment field aggregating the basic Academic disciplines, detailing the contents with specific declaratory according to the new scientific evidences. There are 8 new Academic recruitment field and Group of academic recruitment field aggregating the academic disciplines, larger than the 2 Academic disciplines, and where the health, education (Gaetano, 2012), performance, evaluation and assessment are distinguished in others scientific fields and, there are others related scientific knowledge about the life sciences. 
Only one of the 8 ones is regarding the physical and sport education and it is allocated in not-bibliometric Pedagogical area: 11/D2: DIDACTICS, SPECIAL PEDAGOGY AND EDUCATIONAL RESEARCH "The academic recruitment field is interested in scientific and didactic-training activities ..(..) .. In particular, it deals with research on issues of ..(..) .. education to physical and sports activities." In new rearrangement/organization there are specifically further part of physical and sport education (DM, 2000). Subsequently, it is confirmed into the Ministerial Decree 855 of 30 October 2015 (2015) in the past decree.

The Italian National University Council (CUN), university technical body of Minister of University, helps to simplify the complexity of the academic organization about the Academic disciplines and the Academic recruitment field elaborating the series of keywords as a tool for declination simpler and wider than the declaratory of Academic disciplines on scientific issues. The CUN Opinion of 28 September (2016) "Proposal of a list of keywords, in Italian and English, on the scientific-disciplinary indicators useful for identifying the profile. Proposal of a list of keywords, in Italian and English, concerning the scientific disciplinary descriptors useful for identifying the scientific profile of researchers "(Informa CUN 225, 2018). These keywords have the aim to take in relationship ERC scheme and the Italian Academic disciplines. From the list of the 2400 keywords developed by the CUN, those linked to the essence of physical and sport education ones were chosen. Moreover, from the list have been chosen those related ones in a strict logical of linking with the essential ones for physical and sport education. There are in Italian Language Allenamento, Apprendimento, Benessere, Didattica delle attività motorie e sportive, Pedagogia dello sport e Sviluppo motorio; in English Language are Physical training, Learning, Human movement and sport education, Sport pedagogy and Movement development.

From European union the ERC Panel Structure 2018 aims to do more than simply fund research. It looks to substantially strengthen and shape the all European research system. This is done through high quality peer review, the establishment of international benchmarks of success, and the provision of up-to-date information on who is succeeding and why. So, understanding the new system is essential. The basis on which to develop the reflections is the recent document of the composition of the scientific areas of the classification of "knowledge" as defined. The ERC scheme is composed of 3 main areas: Social and Humanities Sciences, Physical Sciences and Engineering and Life Sciences with a series of panels respectively in the number of 6 for Social and Humanities Sciences, 10 for Physical Sciences and Engineering and 9 for Life Sciences. The simplification is maximum because for all panels there are 333 subpanels structured in 25 specific panels, that is a pyramidal structure where on the basis there are the wide classification of Knowledge fields and at the apex there are the 3 scientific areas. The application of this classification leads to a specific result of an analytical, deductive and comparative process along the subpanels such as the descriptors/keywords with those inherent at the physical and sport education. Specifically, the area is only Social sciences and Humanities with the initials SH (Social Humanities). Following the respective panels and subpanels of the Social sciences and Humanities area as following 2 deductions.

Area SOCIAL SCIENCES and HUMANITIES, Panel SH3 The Social World, Diversity, Population, Subpanel SH3_9 Health and SH3_11 curriculum studies, educational policies

Area SOCIAL SCIENCES and HUMANITIES, Panel SH4 The Human Mind and Its Complexity, Subpanels SH4_1 Cognitive basis of human development and education, SH4_5 Attention, perception, action, consciousness and SH4_6 Learning 


\section{PHYSICAL AND SPORT EDUCATION PERSPECTIVE}

To introduce the perspective of physical and sport education as a function of a definitive arrangement/reorganization of "knowledge field", it is useful to grasp the significant elements of the study and to make a synthesis in order to obtain a construction that can be convincing in used method and obtained results. To grasp in the sign of a single declaration of the Movement and sport science, two approaches can be proceeded:

a) Declining the contents of "knowledge field" and also the methods of research, if different than the research traditions of the scientific area.

b) Following the document evolution by specifying the type of sources: 1) Synthesis of the declaratory of academic disciplines of Movement and sport science, 2) Evolution of the content of Group of academic recruitment field and Academic recruitment field, 3) Collation of the CUN keywords, and finally 4) Collation to ERC Panel Structure 2018. The highest regulatory act of rank with the contents characterizing the scientific identity and which has the most distant backdating is, without a doubt, the law of ISEF Reform which has identified the two new Academic disciplines characterizing and for which the CUN it has determined the denotation in Methods and teaching of the physical activity and Methods and teaching of the sport activities and the subsequently connotation in very specific declaratory. It is from this document that we must start and the genesis of the scientific identity is the identification of specific topics grouped together and belonging physical and sport education:

a) Theory and methodology of human movement (Schimdt et al, 2018, Raiola, 2018, Raiola, DiTore, 2017, Gaetano, 2012ab), of the training (Rago et al., 2017, Meinel, Schnabel, 1986, Matveev, 1972, Bompa, Carrera, 2005) on physical activity for developmental age (Altavilla et al., 2018ab, Arnold, 1988)

b) Theory, technique and didactics of physical activities (Bernstein, 1967, Valentini et al., 2018ab) for the adult and elderly age of the "adapted" physical and sports activities and preventive and compensative physical education (Senatore, D'Elia, 2018, Winnick \& Porretta, 2016)

c) Theory, technique and didactics of physical activities and group sports (Pisapia, D'Isanto, 2018, D'Isanto 2016, Di Tore et al., 2016, Raiola, 2015abc, Teodurescu, 1985), recreational and free time of groups included swimming sports (D'Isanto et al., 2016, Bellotti \& Zanon, 2008)

d) Assessment and evaluation methods (Mazzeo, Raiola, 2018, Mazzeo et al., 2018, Forte, Altavilla, 2018, Zatsiorsky, Kraemer, 2016) and attitudinal in sport (Ferrara, Di Tore, 2018, Tomas, Nelson, 2001, Gaetano, Rago, 2014)

d) Organization of the sports organisms (De lulis, Pescante, 2004).

These themes can be replaced by the CUN keywords selected for Movement and sport science field. As a second moment of synthesis it is advisable to merge the actual declaratory and summarize in application of the drastic simplification request. It could be declined with the same literal modality with which the CUN, from the birth of the physical and sport education (1998) intended to identify them. The Academic disciplines deals with the development and teaching of theories, techniques and methods for general physical and sport education or aimed at particular groups or age groups and for the training and practice of different sports activities and of the performance evaluation/assessment and athletic aptitudes.

Physical and sport education discipline according to CUN keywords and research domains of ERC subpanels. 
It was being identified by the 2400 keywords of Italian National University Council: Physical training, learning, human movement and sport education, sport pedagogy, motor development and by the ERC subpanels: Health, Cognitive basis of human development and education, Learning.

The main issue concerning the full and complete arrangement of "knowledge field" with the European scheme is dealt with by the CUN systematically as a result of the mandate received from the Minister of University with the institution in the official nomenclature of disciplinary groupings replacing respectively of Academic disciplines, Group of academic recruitment field and Academic recruitment field and of the corresponding declaratory. In addition, the CUN also proposed the establishment of research domains also related to disciplinary groupings to fully align with the ERC scheme, which means Areas, Panels and Subpanels. The scientific disciplinary groupings may also be of different research areas and may have various profiles so as to simultaneously guarantee the traditional investigative methodology of analysing the detail and at the same time connecting them transversely with other details of other knowledge. They will have a code, a title and their own declaratory. Alongside the system of scientific disciplinary groupings, the CUN, identifies a taxonomy of research domains also transversal to disciplinary areas, to classify research activities in line with that used by the European Research Council. The research domains will be exclusively aimed at describing and managing research activities, in particular as regards the aspects related to the evaluation of research and projects. Each research domain will be articulated in a series of keywords, defined by the CUN and by the other institutional subjects of the university and research systems, which are representative of the cultural specificities of each study community, so that each researcher can identify those corresponding to the own research activity and community of reference. In the list of keywords may also include the denominations of the profiles used for the description of the disciplinary groupings and, to further delineate their research activity, a series of four to five keywords may be chosen, of who two to three taken from a set encoded used for the articulation of research domains, and another two-three proposal freely. The researcher will indicate, in accordance with the chosen keywords, his main research domain. However, keywords can also belong to different domains, in order to guarantee the possibility of highlighting interdisciplinary research activities. (CUN General Opinion 22, 7/5/2018). For Movement and sports sciences, this arrangement of groupings and domains allows the same modifying treatment to other Academic disciplines, therefore the smallness of the number of university teachers will not weigh negatively as has happened up to now. The ongoing transformation will not take into account the number of structured researchers in university, but will be carried out only on the scientific identity of each academic disciplines and "knowledge field".

Thus, physical and sport education is to be reasonably placed in Social sciences and Humanities area but is away from the rearranged/reorganized and alignment coherently to the subpanels as well as related to them according to the documentary scientific evidences about Movement and sport sciences allocating in Life sciences.

\section{CONCLUSIONS}

It was being identified by the 2400 keywords of Italian National University Council: Physical training, learning, human movement and sport education, sport pedagogy, motor development and by the ERC subpanels: Health, Cognitive basis of human development and education, Learning. The comparison between them is complex but configurable and emerges a gap for the two different method settings because of the misalignment between them. The effect is that the Italian system has a dichotomy between research and training with consequences for grant and funding abroad such as the European Research Council. 
Both method options can be applied according to ERC thought. The way to complete alignment with the ERC scheme of knowledge facilitates the clarification underway for Movement and sport science which, being a young academic discipline, in Italy is struggling to take off for the obstacles placed by the old researchers and the its academic lobby (D'Elia et al., 2018, Raiola, 2018). The definitive scientific identity of Movement and sport science in Italy will have to be achieved also following a downsizing of the Italian National Olympic Committee CONI which carries out its role as manager of sports activities from the position of public body, as if it were a real Ministry of Sport. Of course, research and training are also affected by the action of CONI, which also commits public human and economic resources.

\section{REFERENCES}

Altavilla, G., Mazzeo, F., D’Elia, F., Raiola, G. (2018a)Physical commitment and specific work for each role in an elite soccer team, Journal of Physical Education and Sport, 18 (2), art. no. 83, pp. 570 574.

Altavilla, G., D'Elia, F., Raiola, G. (2018b) A brief review of the effects of physical activity in subjects with cardiovascular disease: An interpretative key, Sport Mont, 16 (3), pp. 103-106. https://doi.org/10.26773/smi.181018

Arnold, P. Education, movement and the curriculum. London: Falmer press, 1988.

Bellotti P, Zanon S., Storia del concetto di allenamento. Perugia, Italy: Calzetti Mariucci, 2008 Bellotti P, Zanon S. Storia del movimento umano. Perugia, Italy: Calzetti Mariucci, 2008.

Bernstein, N.A. The co-ordination and regulation of movements. Oxford : Pergamon Press, 1967. Bompa T, Carrera MC. Periodization training for sports. Champaign, IL: Human Kinetics, 2005.

De lulis A., Pescante M., Storia dell'educazione fisica e dello sport, Monnier, Roma, 2004.

D'elia, F., Mazzeo, F., Raiola, G. (2018)The core curriculum in the university training of the teacher of physical education in Italy, Journal of Human Sport and Exercise, 13, pp. S413-S420. https://doi.org/10.14198/ihse.2018.13.Proc2.25

D'Isanto, T. (2016) Pedagogical value of the body and physical activity in childhood [Pedagoška vrijednost tijela i tjelesne aktivnosti u djetinjstvu] Sport Science, 9, pp. 13-18.

D'Isanto, T., Di Tore, P.A. (2016) Physical activity and social inclusion at school: A paradigm change, Journal of Physical Education and Sport, 16, pp. 1099-1102.

Di Tore, P.A., Schiavo, R., D'Isanto, T. (2016) Physical education, motor control and motor learning: Theoretical paradigms and teaching practices from kindergarten to high school, Journal of Physical Education and Sport, 16 (4), art. no. 205, pp. 1293-1297.

Ferrara, F., Di Tore, P., A., (2018) Preliminary work on the testing of power glove applied to volleyball, Journal of Physical Education and Sport, 18 Supplement issue 5, pp. 1986 - 1990.

Forte, D., Altavilla, G., (2018) Preliminary correlation between anthropometric and performance data in volleyball about the transition period, Journal of Physical Education and Sport, 18 Supplement issue 5, pp.1994 - 1998.

Gaetano, R., Rago, V.(2014)Preliminary study on effects of hiit-high intensity intermittent training in youth soccer players, Journal of Physical Education and Sport, 14 (2), pp. 148-150.

Gaetano, R. (2012a)Motor learning and didactics into physical education and sport documents in middle school-first cycle of education in Italy, Journal of Physical Education and Sport, 12 (2), pp. 157-163.

Gaetano, R.(2012b)Didactics of volleyball into the educate program for coaches/trainers/technicians of Italian Federation of Volleyball (FIPAV), Journal of Physical Education and Sport, 12 (1), pp. 25-29.

Matveev LP. Periodisierang des sportichen treining. Berlin, Germany: Berles end Wernitz, 1972. Matveev L. Fundamentals of sport training. Moscow, Russia: Fizkultura I Sport, 1977 (translated by Albert P. Zdornykh. Moscow, Russia, 1981). 
Mazzeo, F., Raiola, G. (2018). An investigation of drugs abuse in sport performance. Journal of Human Sport and Exercise, 13, pp. S309-S319. https://doi.org/10.14198/jhse.2018.13.Proc2.15

Mazzeo, F., Altavilla, G., D'elia, F., Raiola, G. (2018)Development of doping in sports: Overview and analysis, Journal of Physical Education and Sport, 18 (3), pp. 1669-1677.

Gaetano, R. (2012)Motor learning and didactics into physical education and sport documents in middle school-first cycle of education in Italy, Journal of Physical Education and Sport, 12 (2), pp. 157-163.

Meinel G., Schnabel G., (1984) Teoria del movimento, Roma, Società stampa sportive.

Rago, V., Pizzuto, F., Raiola, G. (2017)Relationship between intermittent endurance capacity and match performance according to the playing position in sub-19 professional male football players: Preliminary results, Journal of Physical Education and Sport, 17 (2), art. no. 103, pp. 688-691.

Raiola, G., D'elia, F., Altavilla, G. (2018) Physical activity and sports sciences between European Research Council and academic disciplines in Italy, Journal of Human Sport and Exercise, 13, pp. S283-S295. https://doi.org/10.14198/jhse.2018.13.Proc2.13

Raiola, G. (2017)Motor learning and teaching method, Journal of Physical Education and Sport, 17, art. no. 236, pp. 2239-2243.

Raiola, G., Di Tore, P.A. (2017)Motor learning in sports science: Different theoretical frameworks for different teaching methods [Motoričko učenje u sportskoj znanosti: Različiti teorijski okviri za različite metode poučavanja]. Sport Science, 10, pp. 50-56.

Raiola, G. (2015a)Inclusion in sport dance and self perception, Sport Science, 8, pp. 99-102.

Raiola, G. (2015b)Basketball feint and non-verbal communication: Empirical framework, Journal of Human Sport and Exercise, 10 (Specialissue1), pp. 360-368.

Raiola, G. (2015c)Sport skills and mental health, Journal of Human Sport and Exercise, 10 (Specialissue), pp. S369-S376.

Raiola, G. (2013)Body knowledge and motor skills, Knowledge Cultures, 1 (6), pp. 64-72.

Pisapia, F., D'Isanto, T., (2018) Inclusive methods of adaptive training in sprints: a theoretical preliminary study, Journal of Physical Education and Sport, 18 Supplement issue 5, pp. $2101-2105$.

Teodurescu L., Teoria e metodologia degli sport di squadra, Società Stampa Sportiva,1985.

Tomas, J.R., Nelson J.K., Silverman S. J., Research method in physical activity (4th edition) Champaign IL USA, 2005.

Schmidt, R, Lee T., Winstein, C., Wulf, G., Zelaznik, H., Motor control and learning, Human Kinetics, IL Champaign, USA, 2018.

Senatore B., D'Elia, F., (2018) Rhythmic gymnastics and dyslexia: a two-year preliminary case study, Journal of Physical Education and Sport, 18 Supplement issue 5, pp. 2122 - 2126.

Valentini, M., Bernardini, C., Beretta, A., Raiola, G. (2018a) Movement and language development as an early childhood twin strategy: A systematic review, Sport Mont, 16 (3), pp. 107-112.

Valentini, M., Riccardi, F., Raiola, G., Federici, A., (2018) Educational research: motor area and relational area during children's personality development, Journal of Physical Education and Sport, 18 Supplement issue 5, pp. $2157-2174$.

Winnick J., Porretta D, (2006) Adapted-Physical-Education-and-Sport-6th-Edition, Human Kinetics IL Champaign, 2016 Zatsiorsky, VM, Kraemer, WJ. Science and practice of strength training. Second Edition. Champaign IL: Human Kinetics.

\section{Document references}

Attachement C \& D Ministerial Decree 855, 30 october 2015, Italy. Attachement A \& B Ministerial Decree 855, 30 october 2015, Italy.

Law n. 18, 16 gennaio 2006, Riordino del Consiglio Universitario Nazionale. 
Attachment ABCD Ministerial decree 4 october 2000.

Law n. 4442, July 7, 1878, Obbligatorietà dell' insegnamento della ginnastica educativa nelle scuole. InformaCUN 225 of 21-23 March 2018.

Law n. 88, 7 febbraio 1958 Istituzione degli Istituti Superiori di Educazione Fisica.

Law n. 16, 16 January 2006, Riordino del Consiglio universitario nazionale.

Law n. 42616 febbraio 1942 Costituzione e ordinamento del comitato Olimpico Nazionale Italiano.

Legislative decree 178, 8 maggio, 1998, Trasformazione degli Istituti Superiori di educazione Fisica e Istituzione della facoltà di scienze motorie e delcorso di diploma e di laurea di scienze motorie. Ministerial Decree n. 855, 30 october 2015, Italy.

Ministerial Decree n. 366, 29 july, 2011, Italy.

Law n. 88, 7 febbraio 1958, Provvedimenti per l'educazione fisica.

\section{Sitography}

https://erc.europa.eu/about-erc/mission

https://erc.europa.eu/sites/default/files/document/file/ERC Panel structure 2018.pdf

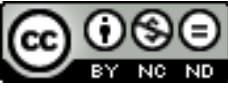

This work is licensed under a Attribution-NonCommercial-NoDerivatives 4.0 International (CC BY-NC-ND 4.0). 